\title{
MIGRANTS AND MEDIA NEWSMAKING PRACTICES
}

\section{Eda Gemi, Iryna Ulasiuk and Anna Triandafyllidou}

European societies are becoming increasingly multicultural and ethnically diverse as a result of immigration. This change, however, is not properly reflected in the European mass media, neither in the portrayal nor in the representation of immigrants in the mainstream media. The aim of this paper is to analyse the newsmaking routines of mainstream newspapers and TV channels in six European countries (Britain, Greece, Ireland, Italy, the Netherlands, Poland) with a view to showing which are the factors that mostly influence these routines. We analyse the impact of three factors on the making of migration related news: a) the news value of such news; b) the role of newsmaking routines and in particular who selects what is published and why; c) the availability of alternative sources and the journalists' trust of different types of news sources. Our study shows that while migrant media follow the general rule that something negative has a higher news value they are also bound up with additional challenges notably that media do not cover migration as a topic regularly, that media outlets have a given 'line' of coverage as regards migration and this contributes to shaping what kind of news are reported. Third, journalists are not always well networked with migrant sources to have access to them. While the rule of thumb "you have to talk to people who are directly involved" holds not all journalists devote the necessary energy and time to present a balanced coverage of migration related issues.

KEYWORDS ethnic diversity; media; migrants; newsgathering; newsmaking;

\section{Introduction}

European societies are multicultural and ethnically diverse as a result of immigration. However, the ethnic and cultural diversity of European societies is not properly reflected in the European media, neither in the portrayal nor representation of immigrants in the mainstream media (Niessen and Huddleston 2010:28). Often the media tend to highlight controversial and conflict aspects of migration rather than opt for well researched, investigative and substantial reports of the social contexts of the relevant news occurrences (van Dijk 1988: 172; Niessen and Huddlestone 2010:46). Existing studies indicate different reasons for these tendencies: the lack of specialised knowledge on migrant issues, the limited time that a journalist has to collect information, the fact that a blunt piece of news has more news 'value' than an elaborate and nuanced account of a complex situation. Unfortunately, this has become a 'fixed repertoire' since news events coverage employs a repetitive chain of statements, actions and conclusions (Law 2010:208). Even when positive reporting does occur, it tends to be presented as the 'exception to the rule' and reflects processes of cultural assimilation with migrant individuals portrayed as successful and 
socially integrated if their creativity and achievements can be framed within the dominant culture (Spoonley and Butcher 2009:4).

Drawing on the growing literature on the subject and the analysis of sixtyeight interviews with senior journalists and media professionals conducted in six European countries (Italy, Greece, Ireland, Great Britain, Poland and the Netherlands) this article studies the impact of three factors on the making of migration related news: a) the news value of such news; b) the role of newsmaking routines and in particular who selects what is published and why; c) the availability of alternative sources and the journalists' trust of and access to different types of news sources.

The article starts with a short sections which makes reference to on the methodology employed and definitions of relevant terms employed in the article. Further our analysis is organised around some fundamental questions that follow the process of news making, notably: What constitutes news when migrants are concerned? To what extent does the political debate influence what is reported on migrants? What are the main sources of migrant news and which voices are 'heard' in the media? In our analysis we present the main findings of our qualitative interviews and contrast or complement them with the results of previous studies.

\section{Definitions}

For most citizens, news is presumably the type of discourse which they deal with most frequently in their everyday lives (van Dijk 1986: 156). In reality, most of people's knowledge and beliefs about the world are shaped primarily by the plethora of news reports that they read, listen to or watch every day. While, according to Tuchman, news is a "product that must be made fresh daily" (1978:179), not everything new happening in the world can be qualified as newsworthy from the point of view of applicability and relevance to the general audience (Brighton and Foy 2007:5). In this context, Bauder observes that news is a kind of "material reference point, on which journalists act to construct meanings of objects and people" (2010: 16). Others adopt the approach which sees news as "a report of what a news organization has recently learned about matters of some significance or interest to the specific community that news organization serves" (Fuller 1996:8).

In fact, Schudson (1997) notes that news is the outcome of a routine bureaucratic system that takes place in a large organisation such as a media outlet. Indeed, the idea of news as a "manufactured product" according to which news constitutes 'a construction of reality rather than a picture of reality' (Whitney et al., 2004:402) predominated during the 1970s. Similarly, Tuchman (1978) and others suggested that media routines and professional procedures systematically construct what is considered as news by selecting and promoting a highly partial range of daily current affairs or issues to the status of newsworthiness (Preston, 2009: 51).

In this article we adopt the view of Tuchman and others that making news is more of a meaning-making exercise rather than a distortion of reality. Thus, the selection of which events to report and the meaning attributed to them (e.g. relating a piece of news to specific other events, people or ideas) is a necessary process. It is a process which is constituted of two important components: the news gathering process (the collection of information from various sources) and the news making process (selecting and organising the information, presenting not only facts but also attributing a certain meaning to them) which have notably evolved in the recent years. 
Until a few years ago, news gathering was structured as a network with news agencies acting as the hub of information. People working for news agencies would feed their reports, text, pictures or other news materials to the agency which would then re-distribute it to media outlets that had a subscription with that particular agency.

The most recent developments in ICT technologies and the development of the social media have profoundly transformed news gathering making it more polyphonic, less professional and less institutionalised. On one hand, the development of smart phones, wireless internet networks, small laptops and digital cameras, and their commercialisation at affordable prices have given a potential journalistic tool to many citizens who can now gather some information and make it readily available to other users and/or to journalists. At the same time the development and quick spread of the social media (Facebook, You Tube, etc.) has helped exchange and share information in a split second with users in other parts of the world without necessarily having this information filtered by the media. The evolution in news gathering practices brought about by the new ICT and social media development has changed the role of the audience, leading to the emergence of participatory journalism (Bruns, 2005: 23). Naturally such participatory journalism is only an emerging feature not a predominant reality. However it acquires an important role when unexpected events are covered (like a murder, a riot or an accident for instance). These features of participatory news gathering may have particular implications in the case of migrant related news as they can foster a bottom-up pluralisation of news sources. We shall return later to the issue of sources of migrant related news.

Concerning news-making Preston in his recent study (2009) adopts the idea of news-making as "a standardized routine" 1 . However, the criteria that frame this standardized news-making routine were firstly identified by Galtung and Ruge (1965). They include: Relevance, Timeliness, Simplification, Predictability, Unexpectedness, Continuity, Composition, Elite peoples, Elite nations, Negativity. Later on, Harcup and O'Neill's (2001) study further elaborated these criteria (earlier introduced by Galtung and Ruge) and instead proposed the following ones: Power elite, Celebrity, Entertainment, Surprise, Bad news, Good news, Magnitude, Relevance, Follow-ups and Media agenda. Among those, we actually identify a set of common dimensions that define the newsworthiness of a given event or piece of information:

- it is easy to understand,

- it conveys a clear meaning (good or bad, black or white, rarely is news 'grey'),

- it usually involves elites (political or other), and

- it has a sense of surprise/unexpectedness.

In its turn, news production is considered to be the outcome of a concrete process which "puts into play the knowledge of the interests and needs of the public, and the ability of the journalist to deliver and process information without distorting reality, selecting and ranking what is news" (De la Torre and Téramo, 2009: 84)².

In reality, the production of news is constrained by numerous routines, practices and organisational limits which influence the selection and presentation of news topics, actors and events (ERCOMER 2002:430). Among the most central factors commonly identified in the literature ${ }^{3}$ are: News values; News scripts $\&$ genres; Ownership, Control and political affiliation; Background, Socialisation and Ethnic group membership of journalists; Differential access (of sources and news actors); 
The relations between press and politics; Editorial policies, including relations between journalist and editor-in-chief.

Finally, the news-making production on immigration issues is primarily related to news gathering on immigrants' events; definition of newsworthiness of migration events; diverse source selection; the identification and contact with immigrant associations, representative spokespersons and experts of immigrant communities (van Dijk 2011: 29).

The news production process does not take into account only the newsworthiness criteria outlined in the previous paragraph but also incorporates issues of power relations, notably the group membership and/or political affiliation of either the people reported or of those who own the specific newspaper or TV/radio channel, and technical issues (the way in which the news genre is constructed before publication and the relationship between an editor and her/his staff). These issues are of special relevance when considering how news on migrants is produced because migrants are politically 'weak': they have limited or no political rights and belong to a national/ethnic/religious minority group, rather than the majority.

\section{News gathering and news making on migrants and migration-related issues}

\subsection{Definition of Migration News}

It has been systematically observed that the majority of media coverage on migration is presented and reported in the news format, whereas editorial articles on the matter and investigative and/or background analysis are almost inexistent. This fact can lead to the hypothesis that the subject of migration is considered as appropriate primarily for the news genre and only from the perspective of information (Tumo, 2010: 6). This is partly due to the limited access of migrants to the media either because of the limited number of migrant journalists employed or because of the endogenous organisational problems of migrants' communities themselves. Migrants have actually less power to influence the sources and mechanisms fuelling the public discourses on which daily news-making is generated (i.e. press conferences and documentation) and also have fewer chances to provide the necessary framework for routine news gathering (Akdenizli et.al. 2008:74).

Furthermore, as various scholars have noted, migrants' opinions are intentionally ignored or found less credible or newsworthy (van Dijk 2000:5). This is partly related to what Koopmans conceptualizes as "the selection process by the mass media" (2004:449). As van Dijk (1991) argues, the media have the tendency to draw on and give preference to "pre-formulations" of concepts and categories articulated by powerful social and political elites. Undoubtedly, in societies where migrants and their associations are not considered part of the political community, it is difficult for them to overcome the selection barriers of the news media which privilege powerful actors with high status and legitimacy (ibid). It is exactly the views and definition of the dominant class - naturalized through media coverage - which ultimately make them seem "normal". They dominate and direct public discourses until they become "common sense" (Jacomelli 2010:91). Presumably, this is why in news reports on immigrants it is commonly the institutions, such as the government, the local or the police authorities, that are accounted for and quoted, and to a lesser extent the representatives of the migrants' associations (van Dijk 1989:6). This media's approach conveniently leaves out the immigrants' voices, which indeed seem unable to challenge the negative definitions that are systematically attributed to them by 
media news reports. Consequently, immigrants, by definition, are broadly represented in the news as speechless actors involved in negative acts (ter Wal 2002: 428).

In our conversations with journalists we made an attempt to investigate to what extent the above comes true with regard to the coverage of such a contentious issue as 'migration', when and what falls under the journalists' scrutiny when migration comes into play. We specifically asked them if they consider that there is such a thing as 'objectivity' in reporting migration news and whether they have a specific perspective from which to look upon migration news.

'Migrant related news is first of all news.'(int.67)

It is common understanding that news is what is timely and different, not routine. The interviewed journalists repeatedly stressed that the media in general are news driven, they are event driven (int. 37, 38). Newsmaking on migrants follows this general pattern. On the one hand, migration news is on most occasions a reaction on what is going on at the moment (int.38, 43, 53, 54, 60, 67) and is, thus, more reactive than proactive. (int. 37) This is even more so in view of a certain 'migrant fatigue' (int.29, 28, 33, 36, 37, 41) and loss of interest in the migration topic observed even in countries traditionally dedicating much attention to diversity issues, including Great Britain, Ireland and the Netherlands. On the other hand, migrant related news also depends on what makes a story from the newsroom, on the extent to which this or that piece of news is found 'meaningful' by the editors (int.43, 56, 68).

To become news a migration story has to meet several criteria. It has to be spectacular! (int.18, 28). By the same token, events which are not pictorial in nature may be relatively neglected by the media. In line with what constitutes 'news' (discussed earlier), migrant news must be interesting (int.51), important and of high visibility (int.38), challenging to people (int.56) and sudden. It must be news that 'touches' the society, changes everyday life (int.58) and impacts on the overall situation. (int.44). As one Dutch journalist noticed, when migrants are concerned, the story of one migrant has to be representative of something, it needs to be broadened and appeal to a wider audience (int.27). Interest seems to be much stronger once a 'national' element is introduced while stories that "only" refer to migrants would normally get less attention (int.36, 59). Migrants per se will not be the focus of the story but rather they would be pictured as one of the elements of a much bigger story (e.g., thousands of refugees fleeing a country because of civil unrests there). If there is a big story (e.g., the publication of the cartoon of Prophet Mohammed in Denmark), then there would be a room for other supporting stories, including migration issues, e.g., Muslim integration in Denmark (int.1). The size and the number of migrants concerned and the impact of the event are all decisive (int. 25). Good examples of such news are recent events in Libya.

\section{'Migrant good news is bad news of course' (int.13)}

The economic interests of the media in gaining and keeping viewers and the current political agenda in most of the European countries under analysis frequently create a bias pushing the migrant-related news toward sensationalism (int.64). As a result, there is a disproportionate (to their actual frequency of occurrence or actual importance for the overall issue of migration and migrant integration) coverage to events involving migrants in episodes of crime, violence, conflict, scandal, scares. (int.9) Negative coverage and 'jump on negative stories' constitute 'news' when 
migrants are concerned (int.10, 34, 44). Immigrants are perceived as a bad thing, especially in those media whose agenda is 'immigration sells newspapers' (int.4). This is for example the case when we look at the common journalistic practice to mention the national origin of a person who has committed a crime (int.59).

News when immigrants are concerned can be anything that is shocking (int.7), anything that goes along the lines of 'migrants are swamping the country'. (8) Immigration is then often perceived as an unfair concurrence and migrants as nothing less than destabilizers of the labour markers of the host countries (int.7). Immigration is perceived as a security problem with stories of migrant involvement into crime, prostitution, black market (int. 34, 52, 54, 61), foreigners breaching visa regimes (int.36), committing homicides (int.47), etc. Immigration is viewed as an economic problem with migrants being intruders into the welfare of the receiving countries (e.g., migrants receiving social welfare payments in the middle of a recession (int.36)), a health threat (e.g. Aids is reported as a disease threat to public health brought by immigrants) (int.7) or 'the conflict of cultures' issue. (int.14)

Most frequently anti-immigration rhetoric, alarmism and consequently a constant drone of hostility are used consciously (int.9). At times this can be done to the extent that when a report is ready and edited, it is edited not to avoid discrimination but rather to 'exacerbate the way the news is presented'. (int.59) It then comes as no surprise that local populations may blame migrants for taking their jobs or for jeopardizing their security and welfare. We can thus assume that many of these discussions are based on emotions and false perceptions about migrants that the media encourage by omitting their voice or the 'other side' of the story that is normally full of abuses, desperation, violent acts at the hand of the police or criminal organisations.

Interestingly, as a senior journalist from Ireland points out, the coverage of immigrants can be in two extremes: very negative and kind of tokenistic, as the examples above demonstrate; and it can be so positive that it becomes unreal (int.34). Some journalists portray migrants only from a positive perspective, and often uncritically, without reflecting "unofficial ordinary discourse" that is going on (int.33).

While sincere advocacy of the wellbeing of immigrants and interest in immigrant lives with which media reply to alarmism are undoubtedly positive in themselves caution should be taken, in our opinion, not to simplify complex issues to the level of anecdotal evidence and not to use these positive instances as a distraction from pressing social issues. Indeed, a balanced view point should be found between the unavoidable negative migrant news and too positive a presentation of migrant reality.

\subsection{Perspectives of Coverage of Migrants' News}

The media have long been seen as an important mechanism in constructing and mediating relations between host and immigrant minorities. Their role has typically been portrayed as endorsing, if not, initiating racist imagery (Spoonley and Butcher 2009:2). The relationship between natives' attitudes and news on immigration has shown that natives' perceptions depend significantly on the presence of newsworthy events which crowd out news on immigration (Jacomelli 2010:12). Many authors have attributed responsibility to the media for promoting negative images of the immigrants. Thus, Van Dijk's (1993) study showed that the media contribute to the reproduction of racist imagery. More recent Spoonley and Butcher's 
(2009) study has demonstrated that in relation to the increasing of public concerns over particular issues, the media play a critical role in transforming negative stereotypes, prejudices and discourses into a heightened sense of crisis, a moral panic. The impact of such moral panic on public opinion is best illustrated in the study of Law, who notes that "in Italy and Greece news coverage was found to be fuelling hysteria or alarm about (the settlement of) immigrants, an alarm which was then appeased by police operations" (Law 2010:208).

Several studies observe the influence of ethnic ideologies on media representation of immigrants. The latter is considered to be largely top-down orientated, especially when it comes to issues about which the general population has no knowledge and no clear attitudes and ideologies (van Dijk 1995:11). For example, what most of the public audiences of the West countries know and believe about Islam is largely due to and shaped by the mass media, rather than by personal experiences and opinions. As Silverstone and Georgiou explain, "it is through these various media that our relations with others, both neighbours and strangers, are facilitated, or, indeed, denied" (Silverstone and Georgiou 2005: 434).

Increasingly, the emphasis in media discourse has been drawn to ethnic and cultural specific characteristics which are supposed to substantially differentiate "others" from "us". This symbolic construction of in-group versus out-group's identities promoted by the media is directly connected with Triandafyllidou's (2000) hypothesis that immigrants disrupt the political and cultural order of the nation by putting a threat to its "purity" and "authenticity". Therefore, they have to be kept 'outside', if not physically then at least symbolically (Boukli 2009: 14). As further elaborated by Ximena Póo (2009), the media symbolic constructions "pass to the public debate, become institutionalized and circulate once again" (cited in Tumo 2010: 7) influencing the way migration issues are understood. As a result, this symbolic construction of migration and migrants by the media legitimizes ethnocentric, nationalist, and xenophobic rhetoric, as immigrants are seen to be the cause of all social problems in European societies.

Indeed, our interviews with media professionals confirm that certain (albeit not all) media outlets send their journalists out to find negative stories about immigrants (int.10). In this case the news tends to be biased. The overriding bias is toward stories that will draw the largest audience, such as criminal stories, stories with conflict, violence, disaster, or scandal. If the only objective of a media outlet is to sell their product at any cost, it is not surprising to find that when migrant-related news is transmitted it often lacks the depth and the voice of the immigrants themselves is not heard at all. In the Italian context, for example, the recent 2011 Lampedusa events regarding the arrival of refugees from Libya clearly showed the reluctance on the part of the media to present the refugees' point of view. In fact, we basically never heard what they thought about what was happening (int.64). So the migrant-related news is often presented from the point of view of the judiciary, authorities, and not those directly involved in the events. At the simplest level, this deprives the coverage of essential context. Audiences exposed to this kind of coverage can readily view immigrants as villains and themselves as victims.

Alternatively, migrants can be just left out as if non-existent (int.35) or even worse a positive instance can be presented as something negative. For example, on occasion of the winning of a prize in the Berlinale on behalf of Greece by an Albanian born film director some right wing newspapers accused the Greek Film Center "of giving money to Albanians whilst Greece is going through an economic crisis". (int.46). 
Despite these rather gloomy findings concerning the perspectives of making migrant news as bad news and of migrants' relative powerlessness to contribute to the news gathering themselves, our interviewees note that the perspective of the coverage is very much dependent on the general line of a media outlet and the type of news at issue (int.8, 60, 67). Thus, if the general line of a media outlet is liberal, open to Europe and critical towards chauvinism (int.19), oriented on objectivity and neutrality of the information (int.22), then the media outlet is more likely to adopt a positive, bridge-building approach towards migrant issues. The resulting product is then likely to be the full, detailed picture of the immigrant image which aims to weaken the strength of the stereotypes still present in different European countries (int. 3, 20). Consequently, stories would present opposing views and reporters would practice journalistic objectivity in the presentation of the events (int.60, 62, 63, 66, 68).

In practice, as journalists explained, in order to offer the audience the account as complete as possible they search for testimonials, for 'voices': via the network of their correspondents, by contacting the protagonists of the stories, trying to make people from different sides talk (victims, culprits, authorities, cultural mediators, associations supporting migrants, etc.) (int. 61). The rhetoric and tone of such reports change and enable to highlight the immigration and the role of immigrants in a more 'cross-cutting' way where immigrants appear as people who share social concerns, challenges, etc. of the society. (int.39)

In short, while past studies point to the overall negative and pejorative bias of migrant news, our study suggests that media perspectives can vary and contain a strong political element in them. Indeed this last point is underscored in the section that follows where we consider the impact of the political agenda on migration news making.

\subsection{Political Agenda and Migration News}

Political debate plays key roles in setting the media agenda and influences what news is to be covered, how, how much, and in what context (int. 33, 61, 62, 63, 64, 65). This regards not only migrant-related news but news in general (int. 64).

On the one hand, the political agenda is important because readers and viewers have a right to know about the political debate surrounding the topic. (int.46, 62) It is also important because when something discussed there is an issue, it stimulates journalists to investigate more bringing to the fore the hidden side of unresolved legal, social and political aspects of migration and see why and whether it is that serious (int.65). It can result in a new story, debates, an interesting interview or analysis, that digs deeper into a certain question (int.31, 20, 50). On the other hand, our informants emphasized that it is equally important for journalists to maintain journalistic independence and not to be overly led by the political agenda (int.22, 31) since it is the political debate that very often links immigration to security, emergency issues accentuating moments when integration does not function properly (int. 65).

The media influence the political debate as well. It is an interactive rather than a one-way process (int.44). The topics which are taken up by the media become the focus of interest of political forces. Thus, in the Polish context, for example, the conflict over a Chechen refugee centre in Lomza was initially covered by the media and only subsequently became an issue for the politicians (int.14). Journalism can thus pose a 'threat' to politicians and bureaucrats, potentially uncovering ineffective policies (e.g. bad condition in refugee centers, discrimination, xenophobia, unfair deportation, delays on absorption of EU social funds for migrants' needs etc.) (int.11, 
53), performing, as one Polish journalist called it, an 'interventionist' function (int.11). Conversely, media inattention can allow governments to continue ineffective policies or worse.

\section{Migrant News out of the political agenda}

Migrant related news are generally biased toward bad news which are seen as more newsworthy. "Good news" stories are less frequently reported. As one journalist put it, they 'get drowned by political agendas' (int.8) and there still remain journalists who do not really make enough use of their right to say whatever they want but rather play it safe because they think that's what the listeners want to hear (even if that might not be true) or what the political agenda dictates (int.34).

The limited coverage of migration issues in the news is very much linked to the lack of immigrant journalists, but also the lack of will to deal with these issues (int. 35). Moreover, it is more difficult to promote 'positive' articles on migration than those negative ones because by the nature of news positive news is not immediately obvious and one needs to discover it and get to it first (int.66). However, it may well be worth recalling that the news profession itself holds investigative reporting in high esteem, creating media pressure toward muckraking. Reporters often see themselves as "watchdogs" of the public interest or even as adversaries of government. Such journalistic activism enables new topics to pop up, including in connection with migration (int.13, 28). Thus, there seems to be a tendency for media in most of the examined European countries to try to go beyond the agenda set by politicians, find new topics, undeveloped issues, areas, undertake various initiatives to make "the other" (the migrant) seen and heard.

Interestingly, 45 out of the 68 journalists interviewed answered affirmatively to the question 'Does your media outlet produce news stories which go out of the political agenda?'; 7 indicated that while there are instances of such reporting, not much space is given to them; 6 answered in the negative; 1 noted that this type of coverage is more characteristic of printed media and not television; 7 journalists did not give a clear answer.

What is then featured outside the political agenda? Topics include an impressive variety of mostly positive news about migrants such as: personal issues (int. 20, 22); human stories (e.g. a story of granting citizenship to a sportsman of migrant origin (int.16); stories on whatever people face in their new home country being parted from their own families (int.43); stories on migrants' accessing social welfare and stories on how migrants are going through the recession (int.41); success stories of when immigrant families have been re-united, stories that focus on the positive contributions migrants make to society; stories showing the human side of migration (e.g., showing how people are fleeing conflicts, i.e., the reasons behind the migration movement) (int.3), cultural news (int. 51).

Some TV, radio stations and newspapers prepare separate programs or pages devoted to immigration issues and immigration people. For example, the Italian newspaper La Reppublica offers to its readers a separate weekly page 'Metropoli' treating all kind of news, information useful both to migrants and Italians who want to know more about migrant-related issues (int.63). RAInews has some in-depth programmes dedicated to immigration related issues (int.64), Dutch NTR offers to its viewers Premtime, a primetime show with historical perspectives for the first generation migrants. (int.24) 
While these initiatives are no doubt positive, they seem to have one recurrent problem. The coverage of immigration remains episodic, producing spikes of coverage and then periods when attention falls off. When a 'different' story is brought to the public's attention, it becomes an issue for a while but is soon forgotten (e.g. suicide of a number of asylum seekers caused by conditions they live in) (int.34) and the news tends to be sporadic rather than regular. (int.67). The surges in coverage of migration news condition the public and policymakers to think of immigration as a sudden event, often tinged with the air of crisis. What seems to be necessary is to cover immigration as a topic in a more continuous, consistent and regular way. Noteworthy in this respect is the initiative which has been undertaken by an Irish TV channel. The RTE has committed itself to producing a series of 6-8 programmes annually on multiculturalism, including migration issue. (int.43)

\subsection{Migration News and Sources}

In an attempt to present a variety of opinions and find new angles in developing stories what are the sources that the journalists use most of the time? Do journalists challenge themselves to find new sources to guarantee objectivity of reporting? Our interviews with senior journalists from six European countries have evidenced that the sources of migrant-related news are indeed numerous but at the same time similar in the countries under analysis.

News agencies as a wholesaler of news play a key role in the agenda setting of the media outlets under examination (int.59, 62, 68). Depending on the type of programme/article in which the news is transmitted, the news from a news agency might or might not be given additional elaboration. If it is minor news or a brief news update, the news provided by a news agency remains intact. Sometimes there may be a short preliminary control of the information or some telephone calls to the persons/institutions who might know/be responsible for the described events. If, on the other hand, there is intention to develop the news received from the agency into a bigger story, journalists then verify its contents meeting the protagonists, giving the floor to different actors, and presenting different points of view. (int.61)

Among the most reliable and most frequently resorted to sources journalists pointed out migrants themselves, migrant communities or people informed about these groups or representing them (int.10, 25, 32, 33, 39, 49, 51, 53,57, 58), migrant and civil society associations (int.36, 45, 46, 48, 61, 62, 63, 64, 67). In this case migration news stories would come directly from the ground, from people connected to migration issues and would entail a lot of original reporting rather than relying on news agencies (int.5).

Indeed, not all journalists rely on news agencies as their main sources (int.8, 65). Thus, sharing her experience, a British journalist noted that: "I speak to people. I tend to go digging. I found out that about $40 \%$ of the printed information is not accurate". She would thus challenge some negative migration story in the press by doing her own research to test it. She would read something she agrees with, something she does not agree with it and then find the balance. (int. 8)

However, journalists should be also careful not to choose the sources only because they are migrant sources. Their relevance to the story is what really matters. As a Dutch journalist rightly points out:

The first thing in journalism is to have the people speak who are directly concerned. And not so much ... the white experts who talk about the groups. 
Not that it is not important, sometimes experts, because of their expertise and contacts, because of their constant involvement can have a good opinion. It is not a matter only of skin colour, but with specialisms. It is not: once you have a Moroccan or Surinamese editor, then you know everything about that community. It depends how this person is informed, his network, and so on. The newsroom needs the diversity to have a diversity of opinions. But you should not give the Moroccan all the Moroccan stories. Search for different sources.(int. 24)

Furthermore, migrant and civil society associations (int.36, 45, 46, 48, 61, 62, $63,64,67)$ play a fundamental role especially in drawing attention to some positive experiences that migrants might have. They serve as a kind of a filter for the promotion of the presence of migrants. In most cases it is they themselves who approach media outlets in order to draw the attention of the society to some burning or positive migration issues which otherwise might be left unattended (int.67).

Various NGOs, human rights/ refugee organizations (int.7, 9, 18, 35, 37, 41, $48,56)$, respective embassies are institutions which provide journalists with the information needed for a migration-related reportage. Yet, another important source is governmental organizations (law enforcement agencies, immigration offices, department of justice, agencies that act on their behalf, etc.) (int.11, 13, 17, 25, 33, 44, $46,49,58,61,63)$.

Then, there are trade unions (int.47, 53, 65), lawyers specialised on migration law or the protection of migrants' rights (int.55), church bodies. (int.33, 67)

Personal contacts of journalists (int.13, 15), journalists' activism in the area (int.33, 34) may well be useful. Also journalists' colleagues of migrant origin usually have the first-hand required knowledge on migrant-related issues and, additionally, they normally have contacts with people competent to speak about immigrant issues. (int.16)

International bodies like the UNHCR (int.33), international media, press agencies, foreign correspondents (int.19), Internet resources (int.22, 49) are also among the sources that provide information on migration issues.

For television outlets an important news source is newspapers (int. 56, 61). As journalists remarked, it may be an outstanding story which was brought to the fore by a daily newspaper which they later try to look at in more detail.

Journalists both search for the news and receive the news from various sources, depending on the needs they have (int. 60, 63, 66). As it has already been mentioned, negative news always becomes public while positive news requires some additional effort on the part of a media outlet and additional investigation into the matter is needed. (int.60)

In sum, journalists seem to have adopted a pluralistic approach in gathering news information. Interestingly, none of our interviewees notes as a significant factor the emergence of new technological developments that allow of grassroots gathering of news in real time. Probably they consider this as part of their everyday job (using smart phones, hence recording audio and video files) not worth mentioning.

Several concerns have been voiced with regard to the information provided by the different sources that journalists consult. Among the biggest problems journalists encounter in search for information are, on the one hand, reluctance/ inability to provide information on the part of migrants themselves and, on the other hand, reluctance to reveal any information on the part of the official institutions (int. 21). 
The validity of what is said on both sides of the argument (int.52) is yet another issue of journalists' concern.

Reluctance of migrants to talk, reluctance to talk on the record, reluctance to give full, accurate facts is primarily dictated by the specificity of the immigration issue itself. Fear of repression, fear for the outcome of the citizenship/residency application, worries about how speaking out might affect their asylum seeker claim, etc. prevent migrants from talking honestly to the journalists (int.21, 33, 35, 39, 45) or require a journalist to be particularly cautious about the anonymity of the sources due to their ambiguous legal status. These problems can be avoided though if migrants know the journalists personally and even more importantly trust them and know that their message will be transmitted correctly to the public (int.11-17, 34, 44,49, 50, 51, $53,68)$.

As an Irish journalist pointed out, when migrants know that it's safe to talk to a journalist, that a journalist will not necessarily present them in a negative light (int. 34), migrants will speak freely about everything. This is even more true of 'migrantrelated' associations which have as their objective making some of the migrantrelated instances public and thus are easily approachable and eager to share the information (int.68). The problem might arise though when the level of migrants' representation is weak (int.54), or when communication is only possible through mediators (especially in the case of first generation migrants) (int.55).

The limited ability of migrants to provide information is primarily due to language and culture barriers. Indeed, immigrants who are likely to have the most pressing social or economic problems are also likely to be those who cannot communicate in the language of the country they find themselves in. While translation with the help of activists and volunteers from NGOs (int. 46, 47, 48, 66) is an effective remedy, several journalists have pointed out that it is sometimes difficult to find somebody to translate who is really trusted by the migrants (int. 39, 41, 45, 48, 57, 61). Moreover, the language barrier poses a technical problem: it necessitates all the interviews to be done in person (while it is common practice in the journalistic profession to use telephone interviews) which requires extra time, resources and effort on the part of the journalists. (int.61)

Concerning official authorities' sources, worries arise as to the validity of the information provided, especially in press releases. A Greek journalist remarked that the ministries' official information is normally formulated in such an ambiguous or obscure way that it is impossible to get any really valuable information from it (int. 53). That is why more information is normally obtained through personal contacts of journalists within ministries than from press releases. Moreover, social workers who on many occasions might be an important source of information are either not allowed to talk to the media or do not have the right skills to do so (int.31). Then doubts also arise as to their independence and their neutrality. In many cases it turns out that they are too committed to the issues they work with and thus neither independent nor neutral in their views. (int.31)

\section{Concluding Remarks}

The analysis of the 68 qualitative interviews with senior journalists as well as our critical review of the relevant scholarly literature on the question of how information about migrants (or the views of migrants for mainstream topics) is gathered and constructed into 'news items' has shown that migrant-related newsmaking practices are shaped by general factors such as the 'news value' of a 
specific item as it probably happens with all types of news. They are however bound up with some challenges that are special to migration related news, notably the general political agenda on migration as well as the 'line' adopted by a given media outlet concerning migration.

More specifically our findings show that news on migration is gathered when something sensational and worth reporting happens. And this is usually something 'bad' related to migrants or migration. Issues that are reported cover personalised, emotion-laden stories that can interest a wider public, stories that show the 'human' and 'everyday' aspect of migration (including families reunited, positive stories of integration, people fleeing conflict or also migrants using and abusing the welfare system) but also make a link to the ethnic element, the ethnic or cultural identity of the migrant.

An additional factor that plays a role in shaping migration related coverage is the fact that media outlets do not cover immigration as a topic continuously. Media tend to flood the media space with instant coverage when something dramatic happens but quickly drop the subject at 'normal' times, thus prompting the public to think of immigration in the "problem/conflict/difficulty" framework.

Journalists are concerned about the quality and even-handedness of their reporting and go beyond the political agenda to cover issues that they see as worth reporting because people want to know more about them. Journalists often consult migrants, migrant communities, NGOs and other non state actors which they consider most reliable for migration related issues. The rule of thumb is: you want to talk to people who are directly involved. However, accessing such 'alternative' sources of information instead of for instance national news agencies, government authorities or academic experts, is not always easy either because many migrants do not trust journalists and are afraid to talk or because the journalist may not have access to the relevant networks so as to build trust. Actually experts can play this role as people who can function as gatekeepers to migrant voices.

Overall there are of course professionals who do an excellent job (diversify their sources, edit their language, present different viewpoints, go beyond the political agenda, are aware of their own preconceptions and seek to present balanced and comprehensive information). But they are not the majority. At the same time the media are facing a historical turning point as technological developments in media and communication as well as free market competition lead to important structural changes (White 2008). Thus on one hand there is more democratisation of the information gathering process and more participatory, citizen journalism. On the other hand, editorial budgets are cut down, the numbers of professional journalists are being reduced while most media professionals are willy-nilly converted to part time freelance workers. There is little investment in training and/or recruitment let alone diversity awareness training. The polyphony of the grassroots sources is met by centralised decisions however as to what is ultimately published, where and when. 


\section{Reference List}

Bauder, Harald. 2010. "Dialectics of Media Practice." Canadian Journal of Media Studies 6 (1): 1-27. http://cjms.fims.uwo.ca/issues/06-01/bauder.pdf (accessed 10 September, 2012)

Banu Akdenizli, E.J. Dionne, Jr. and Roberto Suro. 2008. "A Report on the Media and the Immigration Debate." Paper Series: Democracy in the age of new Media. The Brookings Institute.

http://www.brookings.edu/ /media/Files/rc/reports/2008/0925_immigration_di onne/0925_immigration_dionne.pdf (accessed 10 September, 2012)

Boukli, Evi. 2009. "Human Trafficking in Greece: Media and Legal constructions." Paper presented at the PhD Symposium on Contemporary Greece, Hellenic Observatory LSE, June 25.

Brighton, Paul and Dennis Foy. 2007. News values. London: SAGE

Bruns, Axel. 2005. Gatewatching: Collaborative online news production. New York: Peter Lang.

Cheng, Lifen, Juan J. Igartua, Elena Palacios, Tania Acosta, and Socorro Palito. 2010. "Framing Immigration News in Spanish Regional Press." International Migration. doi: 10.1111/j.1468-2435.2010.00647.x

Downing, John and Charles Husband. 2005. Representing 'Race': Racisms, Ethnicity and Media. London: Sage.

European Institute for Comparative Cultural Research (ERICarts). 2008. "Sharing Diversity: National Approaches to Intercultural Dialogue in Europe." Study for the European Commission. http://www.ericarts.org

Fleras, Augie. 2005. "News Norms as Systematic Bias: Biased Coverage or Coverage that is Biasing?" Waterloo: University of Waterloo

Fuller, Jack. 1996. News values: Ideas for an Information Age, University of Chicago Press, 1996

Jacomella, Gabriela. 2010. "Media and migrations: Press narrative and country politics in three European countries". Reuters Institute Fellowship Paper, University of Oxford.

http://reutersinstitute.politics.ox.ac.uk/fileadmin/documents/Publications/fello ws_papers/2009-2010/Media_and_migrations.pdf (accessed 10 September, 2012)

Hopkins, Liza. 2009. "Media and migration: A review of the field." Australian Journal of Communication, Vol 36, no. 2 (2009), pp. 35-54.

http://researchbank.swinburne.edu.au/vital/access/manager/Repository/swin:14 620 (accessed 10 September, 2012) 
Kontochristou, Maria and Anna Triandafyllidou. 2010. "The Coverage of Minorities in the Media: Greece." Anna Lindh Euro-Mediterranean Foundation for the Dialogue between Cultures.

http://www.euromedalex.org/trends/report/2010/coverage-minorities-mediamaria-kontochristou-anna-triandafyllidou (accessed 10 September, 2012)

Krzyzanowski, Michal and Ruth Wodak. 2006. "Case Studies of Media Discourse: Introductory Note and Comparison of Key Finding." Project report prepared for EMEDIATE, WP4. http://www.eui.eu/RSCAS/Research/EMEDIATE/documents/WP4EMEDIAT EINTROandCOMPARATIVE_000.pdf (accessed 10 September, 2012)

Law, Ian. 2010. Racism and Ethnicity: Global Debates, Dilemmas, Directions. London: Pearson Education.

Niessen, Jan and Thomas Huddleston. 2010. Handbook on Integration for policymakers and practitioners. Third edition. http://ec.europa.eu/ewsi/UDRW/images/items/docl_12892_168517401.pdf (accessed 10 September, 2012)

Preston, Paschal. 2009. Making the News: Journalism and News Cultures in Europe. Abingdon, UK and New York: Routledge

Schudson, Michael. 1997. "The Sociology of New Production." In Social Meanings of News: A Text-Reader edited by Daniel Berkowitz , 7-22. London: Sage

Silverstone, Roger and Myria Georgiou. 2005. "Editorial introduction: Media and minorities in multicultural Europe." Journal of Ethnic and Migration Studies. $31(3), 433-41$.

Spoonley, Paul and Andrew Butcher. 2009. "Reporting Superdiversity. The Mass Media and Immigration in New Zealand". Journal of Intercultural Studies. Volume 30, issue 4, 355-372. http://dx.doi.org/10.1080/07256860903213638 (accessed 10 September, 2012)

Triandafyllidou, Anna. 2000. "Racists? Us? Are You Joking? The Discourse of Social Exclusion of Immigrants in Greece and Italy." In Eldorado or Fortress?

Migration in Southern Europe, edited by Russell King, Gabriella Lazaridis and Charalambos Tsardanidis. London: Macmillan, pp. 186-205.

Tuchman, Gaye. 1978. Making News, A Study in the Construction of Reality. New York: Free Press.

Turmo Sabés Fernando. 2010. "Analysis of the journalistic treatment given to the migration phenomenon in www.elPaís.com." Revista Latina de Comunicacion Social. http://www.revistalatinacs.org/10/art/881_UAB/RLCS art881Eng.pdf (accessed 10 September, 2012) 
van Dijk, Teun A. 2000a. "Ideologies, racism, discourse: Debates on immigration and ethnic issues." In Comparative perspectivas on racism, edited by Jessika ter Wal and Maykel Verkuyten, 91-116. Aldershot: Ashgate.

http://www.discourses.org/OldArticles/Ideologies, \%20racism,\%20discourse.p df. (accessed 10 September, 2012)

van Dijk, Teun A. 2000b. "New(s) Racism: A Discourse Analytical Approach.” In: Ethnic Minorities and the Media, edited by Simon Cottle, 33-49. Milton Keynes, UK: Open University Press. http://www.discourses.org/OldArticles/New\%28s\%29\%20racism\%20$\% 20 \mathrm{~A} \% 20$ discourse $\% 20$ analytical\%20approach.pdf

van Dijk, Teun A. 1999. "Media, Racism and Monitoring.” In International Media Monitoring edited by Kaarle Nordenstreng and Michael Griffin, 307-314. Cresskill, NJ: Hampton Press, 1999. http://www.discourses.org/OldArticles/Media,\%20Racism\%20and\%20Monito ring.pdf. (accessed 10 September, 2012)

van Dijk, Teun A. 1995. “The Mass Media Today: Discourses of Domination or Diversity?". Javnost/The Public (Ljubljana), 2(2), 27-45. http://www.discourses.org/OldArticles/The $\% 20$ mass $\% 20$ media\%20today.pdf. (accessed 10 September, 2012)

van Dijk, Teun A. 1993. Elite Discourse and Racism. London: Sage

van Dijk, Teun A. 1991. "Media contents. The interdisciplinary study of news as discourse." In Handbook of Qualitative Methods in Mass Communication Research, edited by K. Bruhn-Jensen and N. Jankowksi,108-120. London: Routledge. http://www.discourses.org/OldArticles/The $\% 20$ interdisciplinary $\% 20$ study $\% 20$ of\%20news\%20as\%20discourse.pdf (accessed 10 September, 2012)

van Dijk, Teun A. 1989. "Mediating racism. The role of the media in the reproduction of racism." In Language, Power and Ideology, edited by Ruth Wodak, 199226. http://www.discourses.org/OldArticles/Mediating\%20Racism.pdf (accessed 10 September, 2012).

van Dijk, Teun A. 1986. "News Schemata." In Studying Writing. Linguistic approaches, edited by S. Greenbaum and Cooper, 155-186. Beverly Hills, CA: Sage.

White, Aidan. 2008. "To Tell you the Truth.” The Ethical Journalism Initiative, Brussels. http://ethicaljournalisminitiative.org/en. (accessed 10 September, 2012)

\footnotetext{
Notes

${ }^{1}$ A definition introduced by Lippmann in 1922

${ }^{2}$ See http://www.revistalatinacs.org/10/art/881_UAB/RLCS_art881Eng.pdf

${ }^{3}$ ERCOMER 2002, 429-430
} 
${ }^{4}$ Two informants argued that some of their colleagues are not aware of their own prejudice (int.38) and/or do not have enough knowledge about the issue they are reporting on and expressing opinions about (int. 8) so they do not realise the concrete repercussions of their work, of the stereotypes they reinforce, of the ammunition, in effect, that they provide to those in the political arena who do push forth policies of exclusion and xenophobia. It is however difficult to believe that this is the case given that journalists' work is all about news, being read and actually thus inform and shape public opinion. It is difficult to believe that there are journalists who are not aware of this crucial aspect of their work. ${ }^{5}$ It is important to stress that this part of the paper does not aim to analyze the terminology employed in describing migrants but rather the editing procedures used by various media outlets. 